\section{Observation of the Disomic Inheritance of Four Allelic Pairs in the Octoploid Cultivated Strawberry}

\author{
Masanori Honjo ${ }^{1}$ and Susumu Yui \\ NARO Tohoku Agricultural Research Center, 92 Nabeyashiki, Shimokuriyagawa, \\ Morioka, Iwate 020-0123, Japan
}

\author{
Miyuki Kunihisa \\ NARO Institute of Fruit Tree Science, Fujimoto 2-1, Tsukuba, Ibaraki, 305- \\ 8605 Japan
}

Additional index words. Fragaria ×ananassa, diploidized, amphidiploid, allopolyploid, genome composition, simple sequence repeat (SSR)

\begin{abstract}
Although recent genetic studies suggest that octoploid cultivated strawberry, Fragaria $\times$ ananassa Duch., is highly diploidized, there have been no reports that directly and clearly described the behavior of four allelic pairs. In this study, we demonstrated the disomic inheritance of four allelic pairs in $F$. X ananassa by using two highly polymorphic simple sequence repeat markers. By genotyping the offspring of 'Summer-princess' (containing eight distinct alleles of marker FxaHGA02P13) $\times$ 'Dekoruju' (containing another four distinct alleles for this marker), four allelic pairs could be identified in 'Summer-princess'. In a similar way, four allelic pairs could be identified for cultivar Ohishi-shikinari and marker EMFvi136. The results of this study provide direct evidence that at least part of the octoploid strawberry genome is fully diploidized and that the genome composition hypothesis $\mathrm{AAA}^{\prime} \mathbf{A}^{\prime} \mathbf{B B B}^{\prime} \mathbf{B}^{\prime}$ is possible as suggested by other recent genetic studies.
\end{abstract}

The octoploid cultivated strawberry, Fragaria $\times$ ananassa Duch. $(2 n=8 x=56)$, was derived from accidental hybridization between two American octoploid species, $F$. virginiana and $F$. chiloensis, during the early to mid-1700s (Darrow, 1966). It is important to understand the polyploid type of $F$. ×ananassa to develop appropriate breeding strategies and elucidate the phylogeny of this species. Based on cytological and molecular genetic studies, several models of genome composition have been proposed for $F$. Xananassa. Federova (1946) suggested $\mathrm{AABBBBCC}$ on the basis of cytological observations. This was later modified to $\mathrm{AAA}^{\prime} \mathrm{A}^{\prime} \mathrm{BBBB}$ as a result of homologies discovered between the $\mathrm{A}$ and $\mathrm{C}$ genomes (Senanayake and Bringhurst, 1967) and also supported by Rousseau-Gueutin et al. (2009). Later, Bringhurst (1990) suggested $\mathrm{AAA}^{\prime} \mathrm{A}^{\prime} \mathrm{BBB}^{\prime} \mathrm{B}^{\prime}$ based on the cytological work of Byrne and Jelenkovic (1976) and the isozyme segregation patterns reported by Arulsekar et al. (1981). Although it should be noted that the observation of chromosome pairing does not provide definitive evidence for determining polyploid type $(\mathrm{Qu}$ and Hancock, 2001), most cytological studies of

\footnotetext{
Received for publication 23 Apr. 2013. Accepted for publication 9 June 2013 .

We thank Masato Inoue, Setsuko Oki, Yukari Sakurai, and Keiko Iwabuchi for assistance in the greenhouse and technical support in the laboratory.

${ }^{1}$ To whom reprint requests should be addressed; e-mail amhonjo@affrc.go.jp.
}

the species report that bivalent chromosomes 1926; Powers, 1944). Mok and Evans (1971) reported multivalent chromosome associations, but this was attributed to secondary associations of bivalents (Ibrahim et al., 1981). On the other hand, Lerceteau-Köhler et al. (2003) developed linkage maps of the cultivated strawberry by using amplified fragment length polymorphism (AFLP) markers and advocated the hypothesis $\mathrm{AAA}^{\prime} \mathrm{A}^{\prime} \mathrm{BBBB}$ based on a comparison of the number of loci linked in coupling vs. repulsion phase. However, Rousseau-Gueutin et al. (2008) suggested that disomic behavior is predominant in the cultivated strawberry on the basis of comprehensive mapping using AFLP and simple sequence repeat (SSR) markers. Similarly, more recent linkage analysis of the strawberry supports the hypothesis $\mathrm{AAA}^{\prime} \mathrm{A}^{\prime} \mathrm{BBB}^{\prime} \mathrm{B}^{\prime}$ (Sargent et al., 2012). Kunihisa (2011) and the cultivated strawberry was highly diploidized ( $\mathrm{AAA}^{\prime} \mathrm{A}^{\prime} \mathrm{BBB}^{\prime} \mathrm{B}^{\prime}$ ) based on the study of genome-specific markers. Although it is possible that diploidization is still ongoing and that polysomic pairing occurs at a low frequency (Rousseau-Gueutin et al., 2008), recent genetic studies suggest that $F$. ×ananassa is highly amphidiploid.

If the genome formula $\mathrm{AAA}^{\prime} \mathrm{A}^{\prime} \mathrm{BBB}^{\prime} \mathrm{B}^{\prime}$ is correct, it should be possible to detect four allelic pairs from a set of homoeologous loci, although such demonstration using a fourdose marker has not been reported. Highly polymorphic SSR markers, with which it would theoretically be possible to amplify are regularly observed (Ichijima, 1926; Longley, Kunihisa et al. $(2005,2009)$ also reported that eight products from four homoeologous loci, may afford direct evidence for the mode of inheritance in the cultivated strawberry. For example, consider a case in which one parent has eight alleles that can be distinguished from each other and from the allele(s) in the other parent (e.g., $\mathrm{Y}_{1} \mathrm{Y}_{2} \mathrm{Y}_{3} \mathrm{Y}_{4} \mathrm{Y}_{5} \mathrm{Y}_{6} \mathrm{Y}_{7} \mathrm{Y}_{8} \times$ $\left.\mathrm{Y}_{9} \mathrm{Y}_{9} \mathrm{Y}_{9} \mathrm{Y}_{9} \mathrm{Y}_{9} \mathrm{Y}_{9} \mathrm{Y}_{9} \mathrm{Y}_{9}\right)$. In the offspring of this cross, if one or the other of two fragments from the first parent (e.g., $\mathrm{Y}_{1}$ and $\mathrm{Y}_{2}$ ) always appears in the offspring but the two are never inherited together, these two fragments can be inferred to represent an allelic pair. If four such pairs (e.g., $\mathrm{Y}_{1} \mathrm{Y}_{2} / \mathrm{Y}_{3} \mathrm{Y}_{4} / \mathrm{Y}_{5} \mathrm{Y}_{6} / \mathrm{Y}_{7} \mathrm{Y}_{8}$ ) are obtained, it would provide direct evidence for the hypothesis $\mathrm{AAA}^{\prime} \mathrm{A}^{\prime} \mathrm{BBB}^{\prime} \mathrm{B}^{\prime}$

We previously genotyped 75 accessions consisting of $72 F$. xananassa cultivars or selections and three octoploid Fragaria species accessions by using four SSR markers (Honjo et al., 2011). The number of fragments detected within each accession ranged from four to eight for the marker FxaHGA02P13, three to eight for EMFvi136 (Sargent et al., 2003), three to seven for FxaAGA21F11, and five to 12 for EMFv104. The maximum number of fragments, eight, for FxaHGA02P13 and EMFvi136 may suggest that these markers amplify four homoeologous loci and that the individual is heterozygous at each of the loci. By selecting mating parents having different fragment sizes (alleles) for the marker, the two alleles in each pair may be clearly identified.

In this study, we demonstrated the inheritance of four allelic pairs in the octoploid cultivated strawberry by using these highly polymorphic SSR markers.

\section{Materials and Methods}

In a previous study (Honjo et al., 2011), we detected eight fragments for the marker FxaHGA02P13 in the 'Summer-princess' (sizes of amplified fragments were 244, 256, $260,262,265,268,270$, and $302 \mathrm{bp}$ ). These fragment sizes did not overlap with those from 'Dekoruju' (272, 276, 284, and 294 bp). We performed cross-pollination between these cultivars and produced 52 seedlings. Similarly, we produced 47 seedlings from a cross between 'Hogyoku' (244, 256, 260, 268, 270, 273, 286, and $302 \mathrm{bp}$ ) and 'Morioka 34' (262, $265,272,276,284$, and $294 \mathrm{bp}$ ), which also did not have any fragments in common for this marker.

For the marker EMFvi136, eight fragments were detected within 'Ohishi-shikinari' (149, 155, 167, 169, 181, 182, 185, and 189 bp), but other cultivars more or less shared fragments with 'Ohishi-shikinari'. Thus, we attempted to identify allelic pairs by performing crosses to three other cultivars with a variety of fragment sizes. These crosses were 'Ohishi-shikinari' $\times$ 'Harumi' $(149,155,179$, 183, and $191 \mathrm{bp}$ ), 'Ohishi-shikinari' $\times$ 'Mae' $(161,167,179,181$, and $185 \mathrm{bp})$, and 'Ohishishikinari' $\times$ 'Fukuba' $(155,158,183$, and $189 \mathrm{bp}$ ). The number of seedlings analyzed varied from 31 to 58 per cross as a result of the difference of germination rate. 


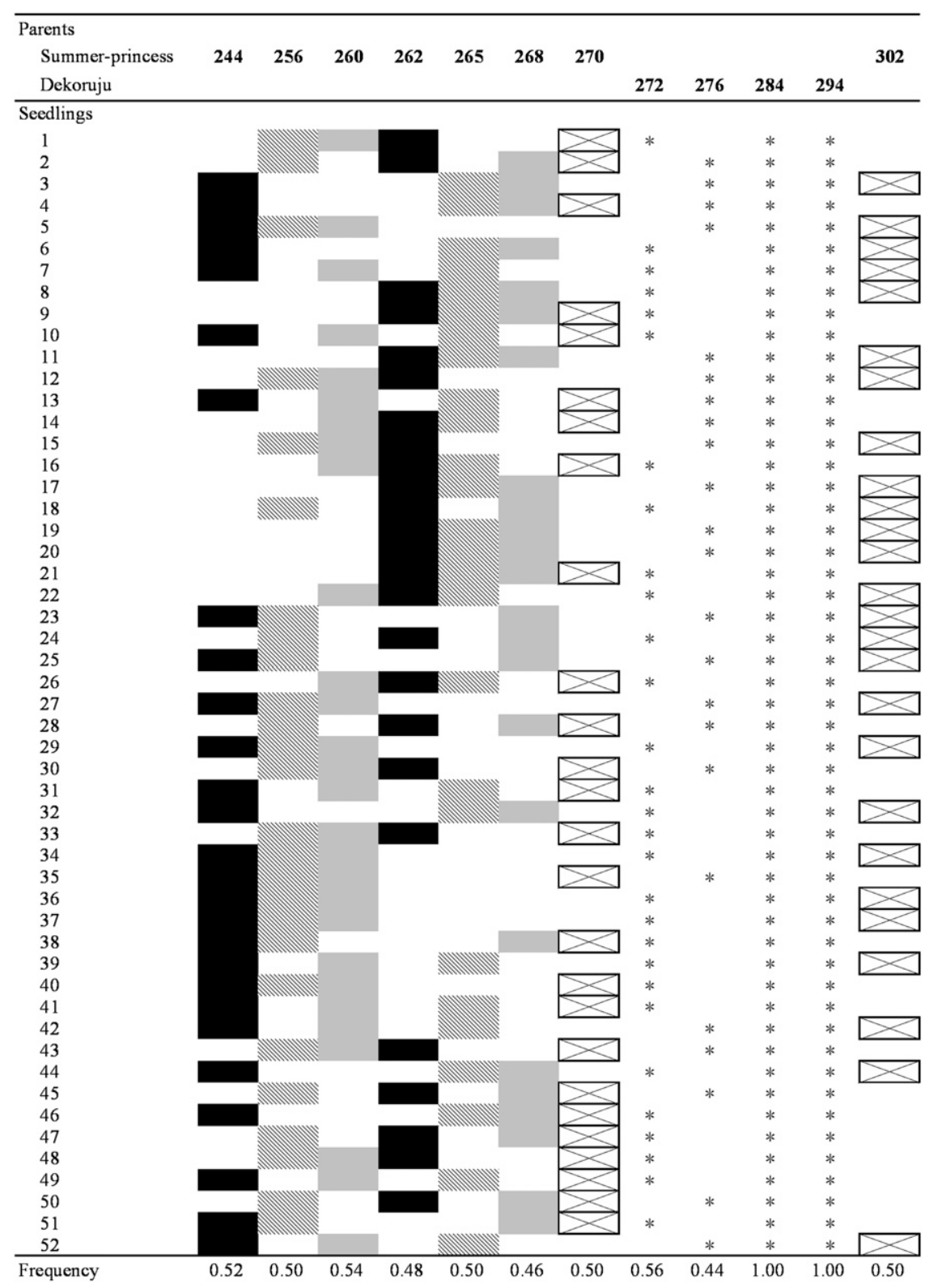

'Summer-princess'

Marker: FxaHGA02P13

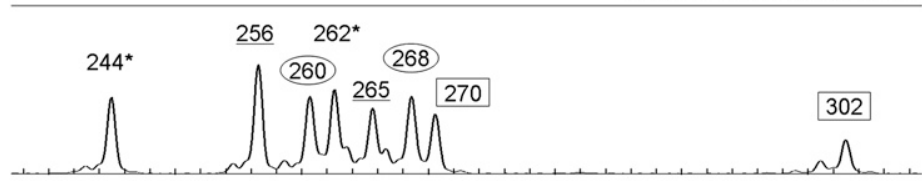

'Hogyoku'

Marker: FxaHGA02P13

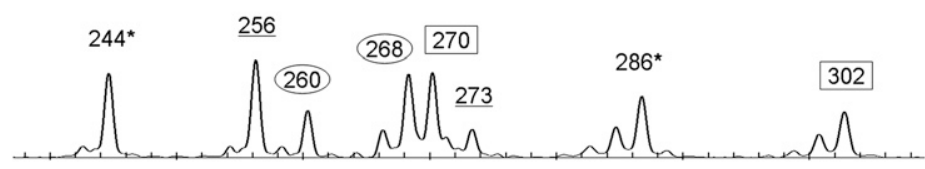

'Ohishi-shikinari’

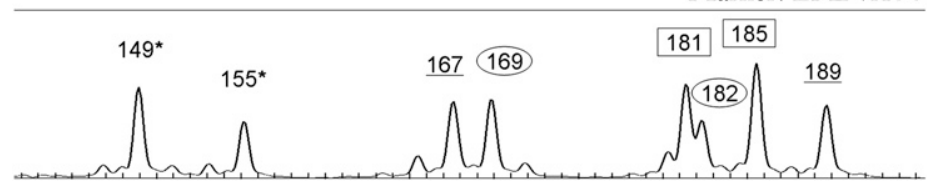

Fig. 1. Amplified fragments of parental cultivars ('Summer-princess' and 'Dekoruju') for marker FxaHGA02P13 and their inheritance in the progeny. A shaded box, a box containing an "X," or an asterisk in a row means that the individual possesses a fragment of the indicated size. Allelic pairs from 'Summer-princess' are indicated by boxes of the same pattern.
Fig. 2. Four allelic pairs of simple sequence repeat (SSR) markers FxaHGA02P13 and EMFvi136 in three octoploid strawberry cultivars. The fragments were separated by capillary electrophoresis. The number above each peak indicates the fragment size (bp). Each allelic pair is indicated by asterisk, underline, circle, and square, respectively. 


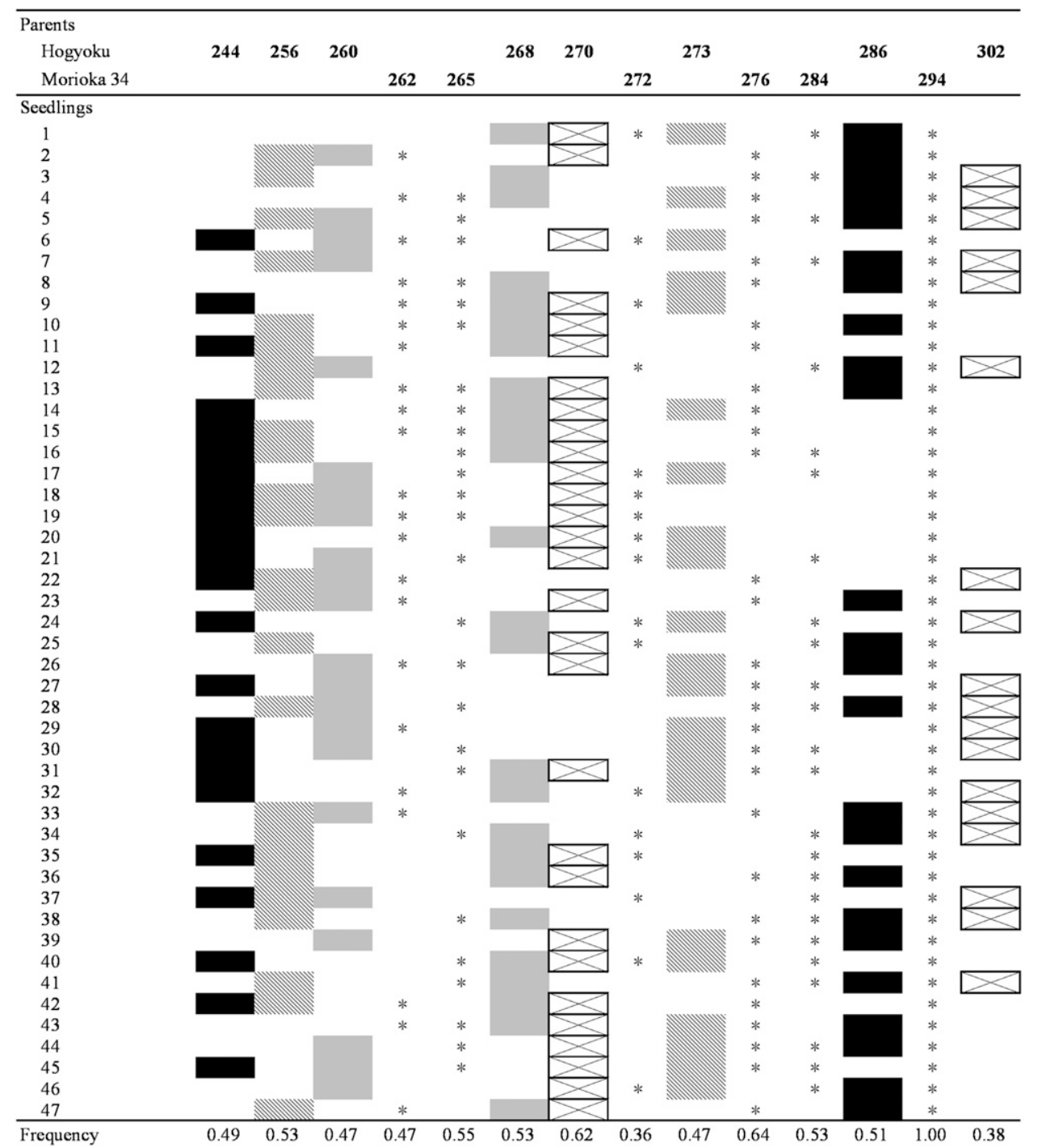

Fig. 3. Amplified fragments of parental cultivars ('Hogyoku' and 'Morioka 34') for marker FxaHGA02P13 and their inheritance in the progeny. A shaded box, a box containing an "X," or an asterisk in a row means that the individual possesses a fragment of the indicated size. Allelic pairs from 'Hogyoku' are indicated by boxes of the same pattern.

Table 1. Chi square test for goodness of fit to a 1:1 ratio of segregating simple sequence repeat fragments in the seedlings of the cultivated strawberry.

\begin{tabular}{lcccc}
\hline Marker & Cross & Allelic pair & $\chi^{2}$ & $P$ \\
\hline FxaHGA02P13 & Summer-princess $\times$ Dekoruju & $244-262$ & 0.077 & 0.782 \\
& & $256-265$ & 0.000 & 1.000 \\
& $260-268$ & 0.308 & 0.579 \\
& & $270-302$ & 0.000 & 1.000 \\
& & $244-286$ & 0.021 & 0.884 \\
EMFvi136 & $256-273$ & 0.191 & 0.662 \\
& & $260-268$ & 0.191 & 0.662 \\
& & $270-302$ & 2.574 & 0.109 \\
& & $167-189$ & 0.610 & 0.435 \\
& & $169-182$ & 1.195 & 0.274 \\
& & $181-185$ & 2.951 & 0.086 \\
& Ohishi-shikinari $\times$ Harumi & $149-155$ & 0.276 & 0.599 \\
& & $169-182$ & 0.069 & 0.793 \\
& & $169-182$ & 1.581 & 0.209 \\
& & $181-185$ & 1.581 & 0.209 \\
\hline
\end{tabular}

Total DNA was extracted from each seedling by using a modified PEG method (Rowland and Nguyen, 1993) with Plant DNAzol Reagent (Invitrogen, Carlsbad, CA) as described by Sugimoto et al. (2005). Polymerase chain reaction (PCR) was performed by the GeneAmp PCR System Model 9700 (Applied Biosystems, Foster
City, CA) and PCR products were run on a CEQ 8000 autosequencer (Beckman-Coulter, Fullerton, CA) as described by Honjo et al. (2011).

\section{Results and Discussion}

In the offspring of 'Summer-princess' $x$ 'Dekoruju' genotyped with the marker FxaHGA02P13, each offspring contained either fragment 244 or fragment 262, but they never appeared together in the same plant (Fig. 1). The same held true for pairs 256 and 265, 260 and 268, and 270 and 302. Thus, four allelic pairs were identified for this marker (Fig. 2). In addition, the data suggested that fragments 272 and 276 of 'Dekoruju' represented an allelic pair. In the same way, fragments 244 and 286, 256 and 273, 260 and 268, and 270 and 302 of 'Hogyoku' and fragments 262 and 284 and 272 and 276 of 'Morioka 34' also appeared to represent allelic pairs (Fig. 3). 


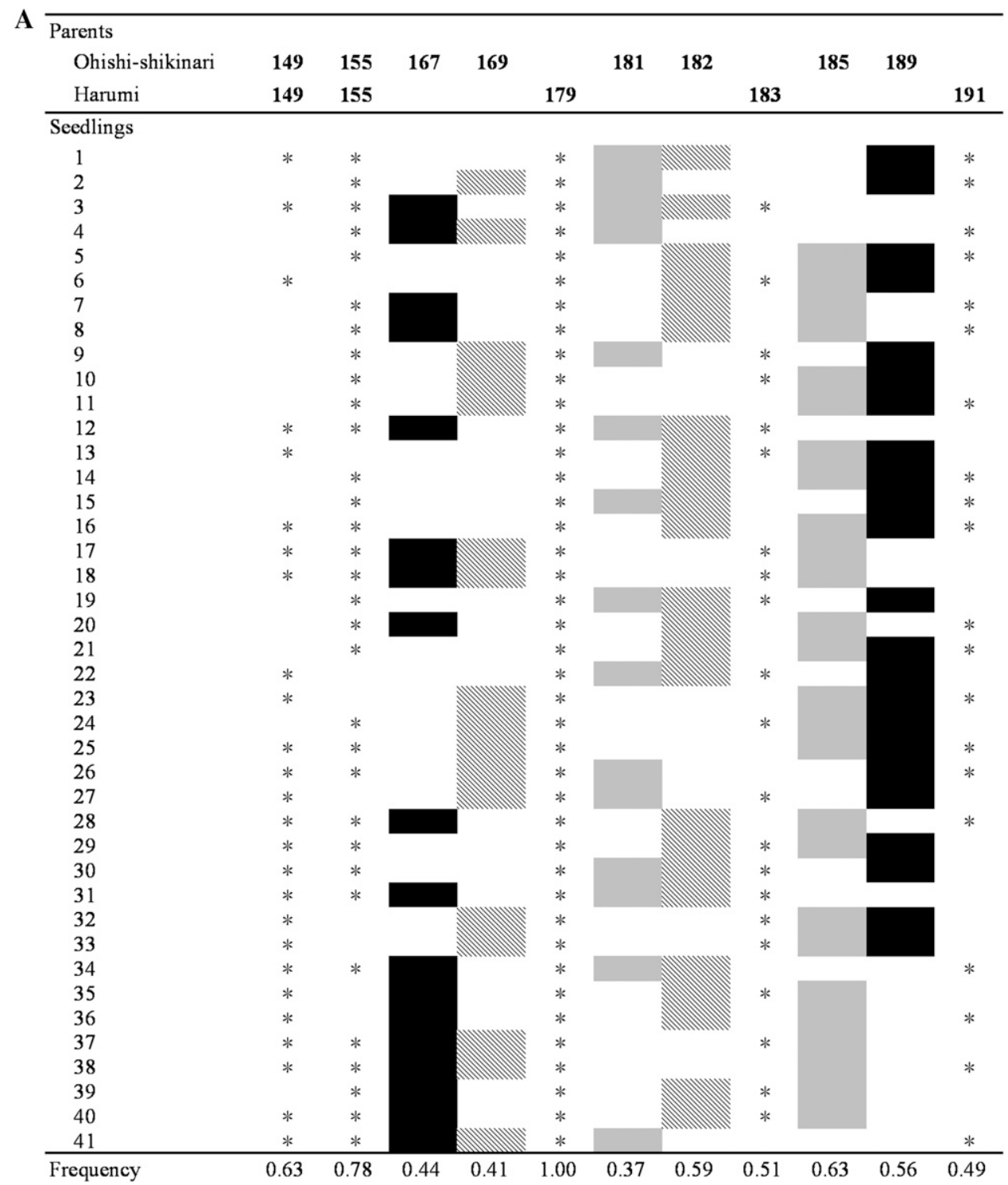

Fig. 4. Amplified fragments of parental cultivars for marker EMFvi136 and their inheritance in the progeny of three crosses: (A) 'Ohishi-shikinari' $\times$ 'Harumi', (B) 'Ohishi-shikinari' $\times$ 'Mae', and $(\mathbf{C})$ 'Ohishi-shikinari' $\times$ 'Fukuba'. A shaded box or asterisk in a row means that the individual possesses a fragment of the indicated size. Allelic pairs from 'Ohishi-shikinari' are indicated by shading.

For EMFvi136, we performed three sets of cross-pollinations. In the offspring of 'Ohishi-shikinari' $\times$ 'Harumi', fragments 167 and 189,169 and 182 , and 181 and 185 of 'Ohishi-shikinari' were inferred to represent three allelic pairs, but the relationship between fragments 149 and 155 could not be determined because they were present in both parents (Fig. 4A). However, in the cross 'Ohishi-shikinari' $\times$ 'Mae', fragments 149 and 155 behaved as an allelic pair as did 169 and 182 (Fig. 4B). From the cross 'Ohishishikinari' $\times$ 'Fukuba', two more pairs of allelic fragments (169 and 182; 181 and 185) were detected (Fig. 4C). As a result, a total of four allelic pairs could be identified for 'Ohishi-shikinari' (Fig. 2). Thus, four allelic pairs were observed for each of the two markers tested.

The segregation ratios were not significantly different from 1:1 in any of the pairs (chi square test: $P>0.05$; Table 1). Although the segregation ratios for some pairs were somewhat skewed, this might be the result of the relatively small number of samples. For example, for the pair 169 and 182 of 'Ohishishikinari', the frequency of allele 169 was less than expected $(41 \%)$ in the offspring of 'Ohishi-shikinari' $\times$ 'Harumi' (Fig. 4A) but more than expected $(61 \%)$ in the seedlings of 'Ohishi-shikinari' $\times$ 'Fukuba' (Fig. 4C) and nearly the expected frequency $(52 \%)$ in the offspring of 'Ohishi-shikinari' $x$ 'Mae' (Fig. 4B).

Several models have been proposed for the genome formula of the octoploid strawberry. Recent genetic mapping studies (Rousseau-Gueutin et al., 2008; Sargent et al., 2012) suggest that strawberry is highly diploidized, whereas Rousseau-Gueutin et al. (2009) supports the hypotheses AAAABBBB or AAA' A $^{\prime}$ BBBB. van Dijk et al. (2012) proposed a method to estimate the microsatellite allele dose and configuration by examining quantitative differences in peak areas; for a specific example from strawberry, the results were consistent with disomic inheritance. However, until now there have been no reports that directly and clearly illustrated the behavior of four allelic pairs. Kunihisa et al. (2005) developed three disomic markers from a single gene, but a fourth locus could not be detected. Here, the behavior of four allelic pairs was clearly visualized by using four-dose SSR markers. EMFvi136 has been mapped to each of the four homoeologous groups in previous linkage analyses (Rousseau-Gueutin et al., 2008; Sargent et al., 2012), providing further evidence that the four disomic pairs observed here correspond to four homoeologous loci. The results of the present study are direct evidence that at least part of the octoploid strawberry genome 


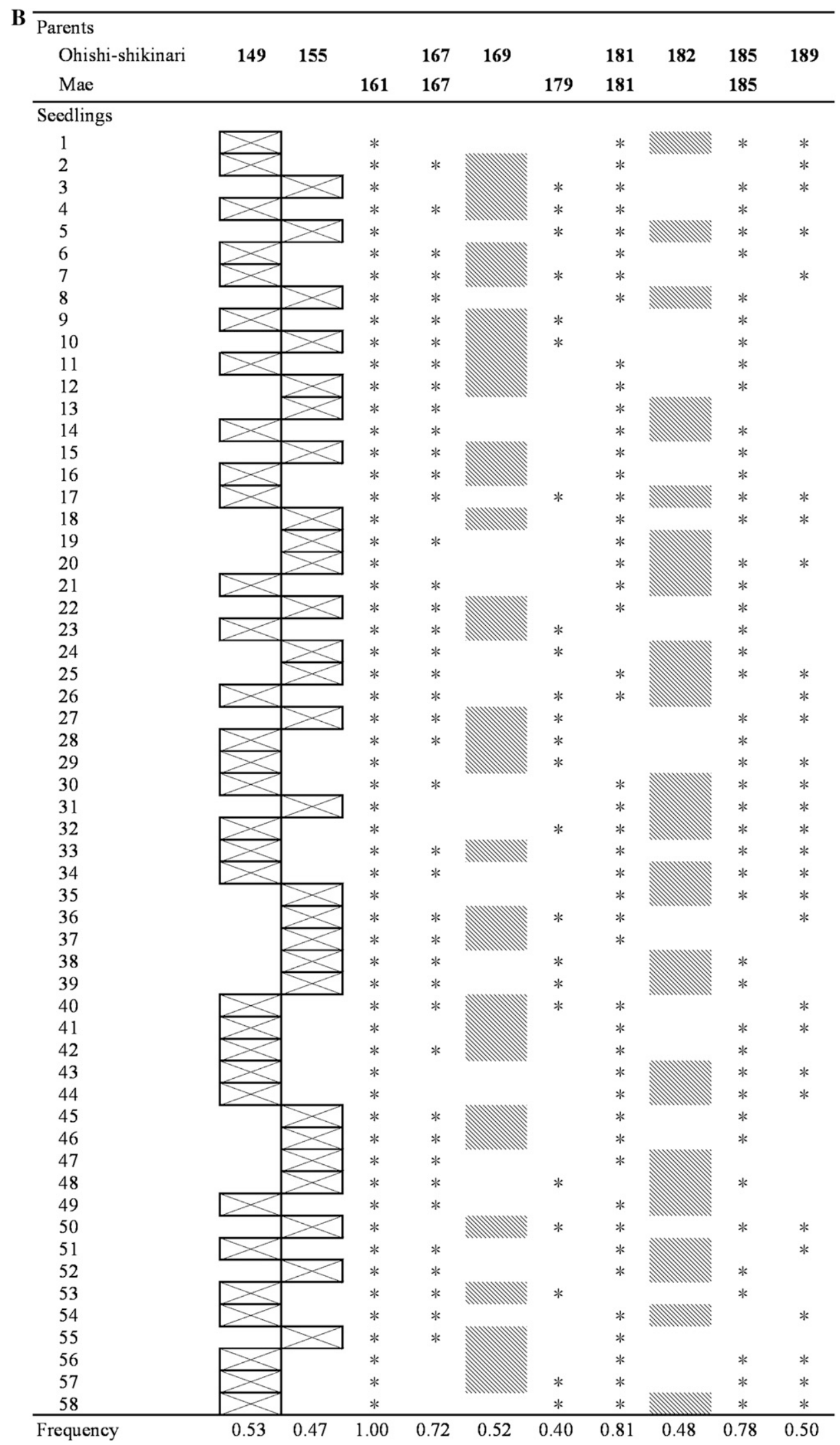

Fig. 4. Continued.

is fully diploidized and that the genome composition hypothesis $\mathrm{AAA}^{\prime} \mathrm{A}^{\prime} \mathrm{BBB}^{\prime} \mathrm{B}^{\prime}$ (Bringhurst, 1990) is possible, as also suggested by the other recent genetic studies described here. There are several reports that agronomically important traits of strawberry such as an everbearing trait (Monma et al., 1990; Sugimoto et al., 2005) and resistance to several pathogens (Haymes et al., 1997; Yamamoto 


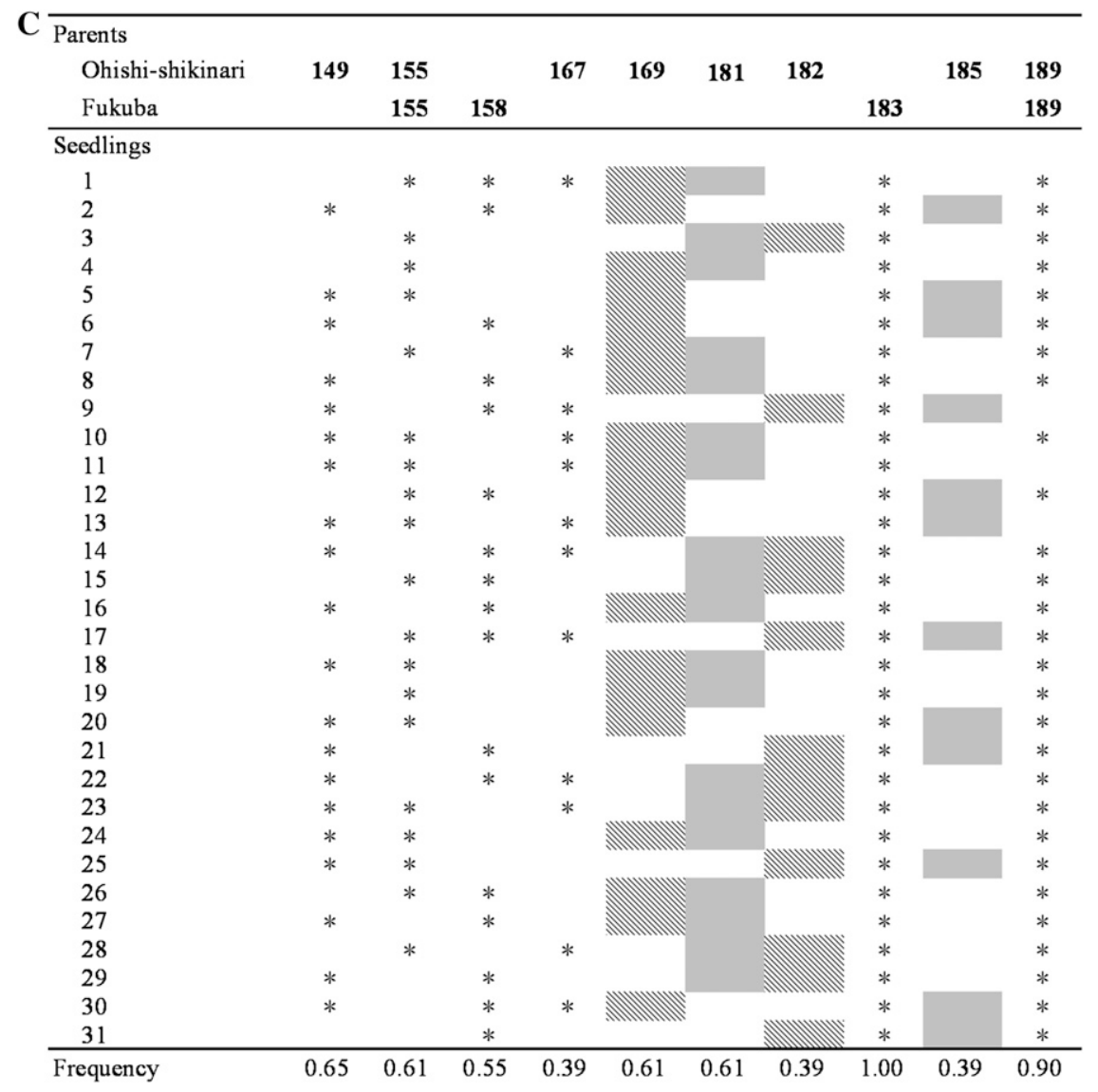

Fig. 4. Continued.

et al., 1985) fit a segregation ratio of $1: 1$ or $3: 1$ in $F_{1}$ populations. If disomic inheritance is predominant in the cultivated strawberry, it will be easier to develop breeding strategies and DNA markers for important traits.

\section{Literature Cited}

Arulsekar, S., R.S. Bringhurst, and V. Voth. 1981. Inheritance of PGI and LAP isozymes in octoploid cultivated strawberries. J. Amer. Soc. Hort. Sci. 106:679-683.

Bringhurst, R.S. 1990. Cytogenetics and evolution in American Fragaria. HortScience 25:879-881.

Byrne, D. and G. Jelenkovic. 1976. Cytological diploidization in the cultivated octoploid strawberry Fragaria Xananassa. Can. J. Genet. Cytol. 18:653-659.

Darrow, G.M. 1966. The strawberry. History, breeding and physiology. Holt, Rinehart and Winston, New York, NY.

Federova, N. 1946. Crossability and phylogenetic relations in the main European species of Fragaria. Comp. Rend. Acad. Sci. USSR 53:545-547.

Haymes, K.M., B. Henken, T.M. Davis, and W.E. Weg. 1997. Identification of RAPD markers linked to a Phytophthora fragariae resistance gene (RpfI) in the cultivated strawberry. Theor. Appl. Genet. 94:1097-1101.

Honjo, M., T. Nunome, S. Kataoka, T. Yano, H. Yamazaki, M. Hamano, S. Yui, and M. Morishita. 2011. Strawberry cultivar identification based on hypervariable SSR markers. Breed. Sci. 61: 420-425.
Ibrahim, A.M.F., K. Sadanaga, and E.L. Denisen. 1981. Chromosomal behavior in octoploid strawberry progenies and their parental clones during meiosis. J. Amer. Soc. Hort. Sci. 106:522-526.

Ichijima, K. 1926. Cytological and genetic studies on Fragaria. Genetics 11:590-604.

Kunihisa, M. 2011. Studies using DNA markers in Fragaria $\times$ ananassa: Genetic analysis, genome structure, and cultivar identification. J. Jpn. Soc. Hort. Sci. 80:231-243.

Kunihisa, M., N. Fukino, and S. Matsumoto. 2005. CAPS markers improved by cluster-specific amplification for identification of octoploid strawberry (Fragaria $\times$ ananassa Duch.) cultivars, and their disomic inheritance. Theor. Appl. Genet. 110:1410-1418

Kunihisa, M., H. Ueda, N. Fukino, and S. Matsumoto 2009. DNA markers for identification of strawberry (Fragaria Xananassa Duch.) cultivars based on probability theory. J. Jpn. Soc. Hort. Sci. 78:211-217.

Lerceteau-Köhler, E., G. Guérin, F. Laigret, and B. Denoyes-Rothan. 2003. Characterization of mixed disomic and polysomic inheritance in the octoploid strawberry (Fragaria $\times$ ananassa) using AFLP mapping. Theor. Appl. Genet. 107:619-628.

Longley, A.E. 1926. Chromosomes and their significance in strawberry classification. J. Agr. Res. 15:559-568.

Mok, D.W.S. and W.D. Evans. 1971. Chromosome associations at diakinesis in the cultivated strawberry. Can. J. Genet. Cytol. 13:231-236.

Monma, S., S. Okitsu, and K. Takada. 1990. Inheritance of everbearing in cultivated strawberry. Bull. Natl. Res. Inst. Veg. Ornam. Plants
Tea Jpn. Ser. C1:21-29 [in Japanese with English abstract].

Powers, L. 1944. Meiotic studies of crosses between Fragaria ovalis and $F$. Xananassa. J. Agr. Res. 69:435-448.

Qu, L. and J.F. Hancock. 2001. Detecting and mapping repulsion-phase linkage in polyploids with polysomic inheritance. Theor. Appl. Genet. 103:136-143.

Rousseau-Gueutin, M., A. Gaston, A. Aïnouche, M.L. Aïnouche, K. Olbricht, G. Staudt, L. Richard, and B. Denoyes-Rothan. 2009. Tracking the evolutionary history of polyploidy in Fragaria L. (strawberry): New insights from phylogenetic analyses of low-copy nuclear genes. Mol. Phylogenet. Evol. 51:515-530.

Rousseau-Gueutin, M., E. Lerceteau-Köhler, L. Barrot, D.J. Sargent, A. Monfort, D. Simpson, P. Arus, G. Guérin, and B. Denoyes-Rothan. 2008. Comparative genetic mapping between octoploid and diploid Fragaria species reveals a high level of colinearity between their genomes and the essentially disomic behavior of the cultivated octoploid strawberry. Genetics 179:2045-2060.

Rowland, L.J. and B. Nguyen. 1993. Use of PEG for purification of DNA from leaf tissue of woody plants. Biotechniques 14:735-736.

Sargent, D.J., A.M. Hadonou, and D.W. Simpson. 2003. Development and characterization of polymorphic microsatellite markers from $\mathrm{Fra}$ garia viridis, a wild diploid strawberry. Mol. Ecol. Notes 3:550-552.

Sargent, D.J., T. Passey, N. Surbanovski, E. Lopez Girona, P. Kuchta, J. Davik, R. Harrison, A. Passey, A.B. Whitehouse, and D.W. Simpson. 
2012. A microsatellite linkage map for the cultivated strawberry (Fragaria $\times$ ananassa) suggests extensive regions of homozygosity in the genome that may have resulted from breeding and selection. Theor. Appl. Genet. 124:1229-1240.

Senanayake, Y.D.A. and R.S. Bringhurst. 1967. Origin of Fragaria polyploids. I. Cytological analysis. Amer. J. Bot. 54:221-228.
Sugimoto, T., K. Tamaki, J. Matsumoto, Y. Yamamoto, K. Shiwaku, and K. Watanabe. 2005. Detection of RAPD markers linked to the everbearing gene in Japanese cultivated strawberry. Plant Breed. 124:498-501.

van Dijk, T., Y. Noordijk, T. Dubos, M.C. Bink, B.J. Meulenbroek, R.G. Visser, and E. van de Weg. 2012. Microsatellite allele dose and configuration establishment (MADCE): An in- tegrated approach for genetic studies in allopolyploids. BMC Plant Biol. 12:25.

Yamamoto, M., F. Namiki, S. Nishimura, and K. Kohmoto. 1985. Studies on host-specific AF-toxins produced by Alternaria black spot of strawberry. (3) Use of toxin for determining inheritance of disease reaction in strawberry cultivar Morioka-16. Ann. Phytopath. Soc. Japan. 51:530-535. 